\title{
ANALISIS SEKTOR UNGGULAN DALAM PEMBANGUNAN DAERAH DI KABUPATEN SIDOARJO
}

\author{
Muhammad Agus Muljanto \\ Politeknik Keuangan Negara STAN \\ agusmuljanto@pknstan.ac.id
}

\begin{abstract}
Regional development planning in the economy as a representation of regional development policies should be oriented to the public interest in regional development. Sidoarjo Regency's economic growth is manifested by an increase in GRDP in the 2016-2020 period (except in 2020, which has decreased due to the COVID-19 pandemic). GRDP is used to evaluate the performance of regional economic development through various development sectors. For this reason, it is necessary to analyze the sectors that are the basis of economic development and the leading sectors that contribute greatly to regional economic growth and these leading sectors become priorities in regional economic development planning. This study aims to determine the basic sector and leading sector as a priority that contributes to the economic growth of Sidoarjo Regency (LQ, DLQ, and Klassen typology methods). The use of quantitative descriptive research methods that describe the phenomenon of what is experienced by the object of research by using numbers. The results of the study show that 14 sectors are prospective in regional development and 1 sector of which is the leading sector as a priority in accelerating economic growth in Sidoarjo Regency, namely the Manufacturing Industry sector. For this reason, a development planning strategy that contributes greatly to regional economic growth can be carried out by giving high priority to the Manufacturing Industry sector.
\end{abstract}

Keywords: Regional Development Planning, Leading Sector, Klassen Typology LQ DLQ Method, Economic Growth

\begin{abstract}
ABSTRAK
Perencanaan pembangunan daerah dalam perekonomian sebagai representasi kebijakan pembangunan wilayah hendaknya berorientasi kepada kepentingan publik dalam pembangunan daerah. Pertumbuhan ekonomi Kabupaten Sidoarjo diwujudkan dengan adanya peningkatan PDRB dalam kurun waktu 2016-2020 (kecuali tahun 2020 mengalami penurunan dikarenakan pandemi covid 19). PDRB dipergunakan untuk mengevaluasi kinerja pembangunan ekonomi daerah melalui berbagai sektor pembangunan. Untuk itu diperlukan analisis terhadap sektor yang menjadi basis pembangunan ekonomi dan sektor unggulan yang berkontribusi besar pada pertumbuhan ekonomi wilayah serta sektor unggulan tersebut menjadi prioritas dalam perencanaan pembangunan ekonomi wilayah. Penelitian bertujuan untuk mengetahui sektor basis dan sektor unggulan sebagai prioritas yang berkontribusi pada pertumbuhan ekonomi Kabupaten Sidoarjo (metode LQ, DLQ, dan tipologi Klassen). Penggunaan metode penelitian deskriptif kuantitatif yang menggambarkan fenomena mengenai hal apa yang dialami oleh objek penelitian dengan menggunakan angka-angka. Hasil penelitian menunjukkan 14 sektor memiliki prospektif dalam pembangunan daerah dan 1 sektor diantaranya menjadi sektor unggulan sebagai prioritas dalam mengakselerasi pertumbuhan ekonomi Kabupaten Sidoarjo, yaitu sektor Industri Pengolahan. Untuk itu strategi perencanaan pembangunan yang berkontribusi besar pada pertumbuhan ekonomi wilayah dapat dilakukan dengan memberikan prioritas tinggi kepada sektor Industri Pengolahan.
\end{abstract}

Kata Kunci: Perencanaan Pembangunan Daerah, Sektor unggulan, Metode LQ DLQ Tipologi Klassen, Pertumbuhan Ekonomi 


\section{PENDAHULUAN}

\subsection{Latar Belakang}

Tantangan besar bagi negara Indonesia yang sedang membangun adalah mampu menghasilkan kebijakan-kebijakan pembangunan yang berorentasi kepada kepentingan publik. Menurut Caiden (1982) hakikat dari disiplin administrasi publik dimaksudkan untuk menanggapi permasalahan dari persoalan masyarakat (public affairs) dan pengelolaan dari usahausaha yang dijalankan masyarakat (public business). Kebijakan pembangunan di negara-negara berkembang pada umumnya merupakan pokok substansi kebijakan publik untuk pengelolaan alokasi sumber daya publik, pemberian layanan publik, pengarahan kegiatan masyarakat, pemberian jaminan ketenteraman dan keamanan. Sedangkan menurut Kartasasmita (1997) urgensi pembangunan suatu bangsa dilakukan dengan 3 (tiga) pendekatan yakni pembangunan makro, pembangunan sektoral, dan pembangunan regional. Cakupan pembangunan makro menyangkut sasaran dan upaya pencapaian pada lingkup makro (nasional) yang mana pemenuhannya merupakan hasil dari beragam upaya capaian pembangunan di tingkat sektoral dan pembangunan di tingkat regional. Untuk itu efektivitas dan efisiensi sistem administrasi pemerintah baik yang berada di pusat maupun yang berada di daerah ikut menentukan keberhasilan perencanaan dan implementasi pembangunan pada umumnya dan pembangunan ekonomi pada khususnya.

Menurut Tambunan (2001) bahwa esensi tujuan pembangunan ekonomi secara nasional dan pembangunan ekonomi daerah tidak memiliki perbedaan secara signifikan meski di daerah proses pembangunannya lebih spesifik. Pertumbuhan ekonomi di daerah dipengaruhi secara spesifik oleh keunggulan komparatif, spesialisasi wilayah, dan potensi ekonomi daerah bersangkutan.
Untuk itu dalam upaya mewujudkan keberlanjutan pembangunan ekonomi di daerah perlu diprioritaskan untuk penggalian dan pengembangan serta pemanfaatan seluruh potensi ekonomi yang dimiliki oleh daerah (Arsyad, 1999). Dalam hal ini peran administrasi publik menjadi relevan di era otonomi berkenaan kewenangan pemerintah daerah agar lebih leluasa dalam pengembangan potensi daerah, pengelolaan sumber kekayaan alam, penentuan arah dan prioritas program pembangunan ekonomi daerahnya.

Tidak adanya daerah yang memiliki karakteristik yang sama baik menyangkut potensi ekonominya, sumberdaya manusianya, serta kelembagaan masyarakatnya, sehingga spesifikasi perbedaan tersebut lebih menentukan warna perencanaan pembangunan di daerah masing-masing (Anggara dan Sumantri, 2016). Pendekatan yang dipergunakan dalam penyusunan perencanaan pembangunan daerah dengan melakukan penggabungan kepentingan baik pemerintahan yang di atas maupun yang di bawah, kepentingan sektoral maupun bidang yang kesemuanya diselaraskan dan diakomodir dalam sebuah perencanaan yang dinamis dan sistematis. Hal ini mendorong terwujudnya perencanaan yang optimal oleh pemerintah pusat dengan pemerintah di daerah serta sektor pembangunan yang merupakan isu utama baik nasional maupun regional (Hafizrianda dan Daryanto, 2010).

Perencanaan Pembangunan Daerah menurut Peraturan Pemerintah No. 8 tahun 2008 adalah tahapan proses penyusunan kegiatan yang mencakup berbagai unsur pemangku kepentingan didalamnya dalam pemanfaatan dan pengalokasian sumber daya untuk meningkatkan kesejahterahan sosial di lingkungan wilayah atau daerah dengan jangka waktu yang telah ditentukan. Dengan demikian secara implisit tujuan perencanaan pembangunan daerah antara lain dimaksudkan untuk mencapai tujuan 
perekonomian berupa peningkatan pertumbuhan ekonomi daerah. Pemerintah daerah dalam implementasi perencanaan pembangunan membutuhkan resources untuk dikelola mencakup penggunaan sumber daya yang dianggap potensial dalam rangka memaksimalkan pencapaian tujuan pembangunan dan mengakselerasi pertumbuhan ekonomi.

Menurut Arsyad (2004) bahwa pertumbuhan ekonomi merupakan salah satu indikator utama keberhasilan pembangunan suatu daerah. Pertumbuhan ekonomi adalah perkembangan dengan dimensi tunggal yang diukur berupa peningkatan hasil produksi dan pendapatan. Dalam hal ini adanya kenaikan dalam pendapatan berupa besaran nilai Produk Domestik Regional Bruto (PDRB). Produk Domestik Regional Bruto merupakan salah satu indikator ekonomi makro yang digunakan untuk perencanaan kebijakan pembangunan daerah, penetapan arah dari pembangunan daerah, untuk mengevaluasi hasil dari pembangunan daerah, dan sebagai indikator laju pertumbuhan ekonomi sektoral untuk mengetahui sektor mana saja yang menjadi penyebab perubahan secara signifikan dalam pertumbuhan ekonomi wilayah. PDRB yang semakin laju pertumbuhannya menunjukkan semakin meningkatnya pertumbuhan ekonomi daerah sehingga mempercepat pembangunan daerahnya.

Berkenaan dengan penelitian yang relevan sebelumnya terdapat beberapa sektor unggulan di beberapa daerah yang berdekatan dengan Kabupaten Sidoarjo atau yang berada di kabupaten di Propinsi Jawa Timur. Menurut Irmansyah (2019) terkait data PDRB Kabupaten Mojokerto pada tahun 2015-2016 dengan hasil dari penelitian menunjukkan adanya sektor unggulan yang harus diprioritaskan di Kabupaten Mojokerto yakni sektor real estate dan sektor industri pengolahan. Lebih lanjut menurut Hakim (2019) sebagai sektor unggulan di Kabupaten Gresik tahun 2011-2017 memiliki 3 (tiga) sektor, yaitu sektor industri pengolahan, sektor pertambangan dan penggalian, dan sektor pengadaan listrik dan gas. Untuk sektor unggulan di Kabupaten Bangkalan yang terletak di pulau Madura di tahun 20152019 adalah sektor pertanian, sektor kontruksi, sektor transportasi dan pergudangan, dan sektor jasa pendidikan (Rohmah dan Cahyono, 2021). Sedangkan menurut Budi T (2019) di Kabupaten Blitar yang berada di kawasan selatan propinsi Jawa Timur dalam rentang tahun 2010-2016 ditopang oleh 4 (empat) sektor yakni sektor industri pengolahan; sektor pertanian, kehutanan, dan perikanan; sektor perdagangan besar dan eceran, reparasi mobil dan sepeda motor; dan sektor konstruksi. Dari keempat penelitian terdahulu yang dilakukan di Kabupaten Mojokerto, Kabupaten Gresik, Kabupaten Bangkalan, dan Kabupaten Blitar tersebut, penulis lebih menitikberatkan terhadap peran perencanaan pembangunan daerah dalam perekonomian sebagai representasi kebijakan pembangunan wilayah hendaknya berorientasi kepada kepentingan publik dalam pembangunan daerah yang dilakukan oleh Pemerintah Kabupaten Sidoarjo.

Pada artikel ini dilakukan analisis terhadap PDRB Kabupaten Sidoarjo dari tahun 2016 sampai dengan 2020 yang mengalami peningkatan setiap tahunnya (kecuali tahun 2020 dikarenakan wabah pandemi). Peningkatan tersebut menunjukkan adanya pertumbuhan ekonomi wilayah di Kabupaten Sidoarjo. Pertumbuhan ekonomi suatu wilayah didasarkan pada berbagai sektor pembangunan. Oleh karenanya diperlukan analisa dalam strategi sektor unggulan yang memiliki kontribusi besar terhadap pertumbuhan ekonomi wilayah.

Sektor unggulan tersebut dapat menjadi prioritas dalam perencanaan pembangunan ekonomi wilayah. Dengan demikian strategi perencanaan pembangunan dilakukan berdasarkan potensi sektoralnya. 
Dengan melakukan perbandingan dengan wilayah yang lebih luas diatasnya yakni provinsi Jawa Timur, maka dapat diketahui sektor yang menjadi unggulan di Kabupaten Sidoarjo. Dengan demikian untuk mengetahui sektor yang menjadi basis pembangunan ekonomi dan sektor unggulan yang berkontribusi pada pertumbuhan ekonomi di Kabupaten Sidoarjo dianalisa dengan metode Location Quotient (LQ), Dynamic LocationQuotient (DLQ), dan tipologi Klassen.

\subsection{Rumusan Masalah}

Berdasarkan pembahasan latar belakang yang diuraikan diatas, rumusan masalah yang dibahas adalah :

- Sektor apakah yang menjadi basis pembangunan ekonomi di Kabupaten Sidoarjo?

- Sektor unggulan apakah yang berkontribusi pada pertumbuhan ekonomi di Kabupaten Sidoarjo?

\subsection{Tujuan Penelitian}

Berkenaan dengan latar belakang dan rumusan permasalahan yang sudah diuraikan diatas, maka tujuan penelitian ini adalah:

- Mengetahui sektor yang menjadi basis pembangunan ekonomi di Kabupaten Sidoarjo.

- Mengetahui sektor unggulan apa yang berkontribusi pada pertumbuhan ekonomi di Kabupaten Sidoarjo.

\subsection{Permasalahan}

Keberhasilan pembangunan ekonomi di daerah memiliki kontribusi dalam capaian keberhasilan pembangunan nasional. Keberadaan perekonomian nasional disusun dari keberadaan perekonomian di daerah sehingga keberhasilan dari pembangunan di daerah turut menentukan kesuksesan pembangunan nasional. Untuk meningkatkan pertumbuhan ekonomi daerah sebagai salah satu indikator dalam keberhasilan pembangunan Kabupaten Sudoarjo diperlukan strategi dalam penentuan sektor prioritas yang menjadi unggulan.

Sehubungan hal tersebut, diperlukan analisis terhadap sektor-sektor perekonomian yang secara potensial dapat bersaing dan memacu pertumbuhan ekonomi. Dengan demikian perencanaan pembangunan ekonomi dilakukan secara terstruktur berdasarkan potensi sektoralnya. Ditinjau dari PDRB Wilayah Kabupaten Sidoarjo terdapat 3 (tiga) sektor yang secara nominal memiliki kontribusi paling besar, yaitu sektor Industri Pengolahan; sektor Konstruksi; dan sektor Perdagangan Besar dan Eceran, Reparasi Mobil dan Sepeda Motor. Meski demikian, ketiga sektor tersebut belum dapat dipastikan menjadi sektor unggulan sehingga diperlukan analisis untuk mengetahui sektor unggulan yang berpotensi besar meningkatkan pertumbuhan ekonomi.

\subsection{Reviu Pustaka}

Hubungan secara langsung terhadap permintaan barang dan jasa dari luar daerah menjadi faktor yang menentukan adanya pertumbuhan ekonomi di daerah (Richardson, 1973) Adanya pertumbuhan industri di daerah dengan penggunaan sumber daya daerah termasuk pengunaan bahan baku dan tenaga kerja untuk keperluan ekspor dapat menambah kekayaan daerah dan penciptaan kesempatan kerja. Dengan demikian suatu daerah akan memiliki sektor unggulan bilamana daerah bersangkutan berhasil atau menang dalam persaingan pada sektor yang sama terhadap daerah lain sehingga bisa menghasilkan ekspor.

Teori basis ekonomi (economic base theory) merupakan salah satu teori ekonomi yang menekankan hubungan antara sektorsektor yang terdapat dalam perekonomian daerah. Konsep dasar dari teori basis ekonomi membagi perekonomian menjadi 2 (dua) sektor yaitu sektor basis dan sektor bukan basis (Glasson, 1990). Yang dimaksud dengan sektor basis adalah sektor-sektor yang mengekspor barang atau jasa ke luar 
daerah atau ke luar batas perekonomian masyarakat. Sedangkan yang dimaksud sektor bukan basis adalah sektor-sektor yang menjadikan barang atau jasa yang dibutuhkan masyarakat pada daerah yang bersangkutan dan tidak melakukan ekspor barang atau jasa ke luar daerah.

Peningkatan kegiatan ekonomi pada sektor basis akan menambah pendapatan daerah yang berikutnya meningkatkan adanya permintaan terhadap barang atau jasa sektor bukan basis dan giliran selanjutnya meningkatkan kegiatan ekonomi pada sektor bukan basis. Sebaliknya, apabila penurunan kegiatan ekonomi pada sektor basis dapat menyebabkan penurunan pendapatan daerah yang berikutnya akan menurunkan permintaan terhadap barang atau jasa sektor bukan basis. Dengan demikian kegiatan perekonomian pada sektor basis mempunyai peran sebagai penggerak utama. Bahwa konsep utama teori basis ekonomi dimana kegiatan ekspor sebagai pendorong utama adanya pertumbuhan. Untuk itu tumbuh tidaknya suatu wilayah lebih ditentukan kinerja wilayah bersangkutan terhadap adanya permintaan barang dan jasa dari luar.

Cara penentuan apakah suatu sektor merupakan sektor basis atau sektor bukan basis adalah dengan analisis Location Quotient (LQ). Location Quotient adalah perbandingan dari jumlah produksi atau pemberian nilai tambah pada sektor tertentu di suatu wilayah terhadap jumlah produksi atau nilai tambah untuk sektor yang sama pada suatu daerah yang memiliki cakupan administratif yang lebih luas. Tujuan penggunaan metode LQ adalah melakukan identifikasi sektor basis atau sektor unggulan pada suatu wilayah. Adapun formulanya yaitu:

$$
L Q=\frac{X i j / R V j}{X i / R V i}
$$

LQ = Indeks/koefisien Location Quotient dari Sektor i di wilayah j

$\mathrm{X} \mathrm{ij}=$ PDRB sektor $\mathrm{i}$ pada wilayah $\mathrm{j}$
$\mathrm{Xi} \quad=$ PDRB sektor i pada wilayah tingkat atas(provinsi/nasional sebagai acuan)

$R V j=$ Total PRDB pada wilayah $\mathrm{j}$

$\mathrm{RVi}=$ Total PDRB di wilayah tingkat atas (provinsi/nasional sebagai acuan)

Jika nilai $L Q<1$, maka sektor tersebut kurang terspesialisasi dibanding dengan sektor yang sama pada tingkat daerah tertentu, sehingga bukanlah sebagai sektor basis. Apabila nilai LQ $>1$, maka sektor tersebut lebih terspesialisasi dibanding sektor yang sama pada tingkat daerah tertentu, sehingga sebagai sektor basis dan sebagai sumber pertumbuhan. Produk pada sektor tersebut tidak hanya dapat mencukupi kebutuhan di wilayah tersebut saja namun bisa diekspor ke luar wilayah. Kontribusi sektor tersebut terhadap PDRB adalah lebih besar dibandingkan sektor yang sama pada wilayah tingkat atas.

Metode analisa LQ dibagi menjadi 2 (dua) bagian, yaitu statis (Static Location Quotient) dan dinamis (Dynamic Location Quotient). Dynamic Location Quotient sebagai perkembangan lebih lanjut dari SLQ. DLQ merupakan analisa LQ yang dilakukan secara time series, dimana perkembangan LQ dapat dimonitor untuk suatu sektor tertentu dalam kurun waktu yang memang berbeda, untuk mengetahui apakah terjadi penurunan atau peningkatan (Tarigan, 2009). DLQ dihitung dengan memasukkan laju pertumbuhan rata-rata terhadap suatu sektor maupun PDRB pada kurun waktu antara tahun 0 hingga tahun $\mathrm{t}$. DLQ dihitung dengan menggunakan rumus:

$$
\mathrm{DLQ}=\left(\frac{(1+\mathrm{gik}) /(1+\mathrm{gk})}{(1+\mathrm{gtp}) /(1+\mathrm{gp})}\right)^{t}
$$

gik = rata-rata pertumbuhan PDRB sektor $\mathrm{i}$ di wilayah $\mathrm{k}$

gk = rata-rata pertumbuhan total PDRB di wilayah $\mathrm{k}$

gtp = rata-rata pertumbuhan PDRB sektor i di wilayah tingkat atas (p)

$\mathrm{gp}=$ rata-rata pertumbuhan total PDRB di wilayah tingkat atas (p) 


\section{$\mathrm{t}$ = waktu (tahun)}

Jika DLQ lebih besar dari 1 (DLQ>1), maka berakibat potensi pengembangan sektor $\mathrm{i}$ di wilayah $\mathrm{k}$ lebih cepat dibandingkan sektor yang sama pada wilayah tingkat atas atau disebut prospektif. Jika DLQ lebih kecil dari 1 (DLQ<1), maka potensi pengembangan sektor i di wilayah $\mathrm{k}$ lebih rendah dibandingkan sektor yang sama pada wilayah tingkat atas atau disebut tidak prospektif.

\section{METODE PENELITIAN}

Penggunaan metode penelitian adalah deskriptif kuantitatif dengan memberikan gambaran fenomena perihal apa yang terjadi atau dialami oleh objek penelitian dengan penggunaan angka-angka. Objek penelitian dimaksud yakni Produk Domestik Regional Bruto Kabupaten Sidoarjo dan Produk Domestik Regional Bruto Provinsi Jawa Timur dengan penggunaan Tahun Dasar 2010 periode 2016 - 2020. Pengunaan jenis data adalah data kuantitatif yaitu berupa data statistik dengan sumber data berupa data sekunder yang diakses dari website Badan Pusat Statistik. Teknik pengumpulan data dilakukan dengan studi kepustakaan yaitu dengan mendalami data yang tersedia pada website resmi BPS. Berkenaan dengan penggunaan alat analisisnya yaitu analisis LQ, DLQ, dan tipologi Klassen.

Adapun garis besar alur logika (kerangka pemikiran) penelitian ini dituangkan pada diagram sebagaimana tampak pada gambar 1 . Tahap awal penelitian dilakukan dengan melakukan studi pendahuluan untuk memperoleh atau menghimpun informasi mengenai Sektor Lapangan Usaha dan PDRB Kabupaten Sidoarjo. Setelah dilakukan studi pendahuluan, tahap berikutnya dilakukan identifikasi masalah, yaitu terkait penentuan sektor-sektor perekonomian yang berpotensi untuk meningkatkan pertumbuhan ekonomi daerah. Langkah berikutnya yaitu studi pustaka terkait PDRB Kabupaten Sidoarjo dan pengumpulan data. Data yang dikumpulkan berupa Produk Domestik Regional Bruto Atas Dasar Harga Konstan Tahun 2010 untuk Kabupaten Sidoarjo dan Provinsi Jawa Timur di tahun 2016-2020. Selanjutnya data tersebut dianalisis dengan menggunakan metode LQ dan DLQ. Hasil dari penggunaan metode LQ dan DLQ selanjutnya digunakan untuk menentukan potensi unggulan sebagai prioritas daerah dengan penggunaan tipologi Klassen. Dari hasil analisis data yang diperoleh, kemudian dilakukan pembahasan dan pemberian simpulan dan saran.

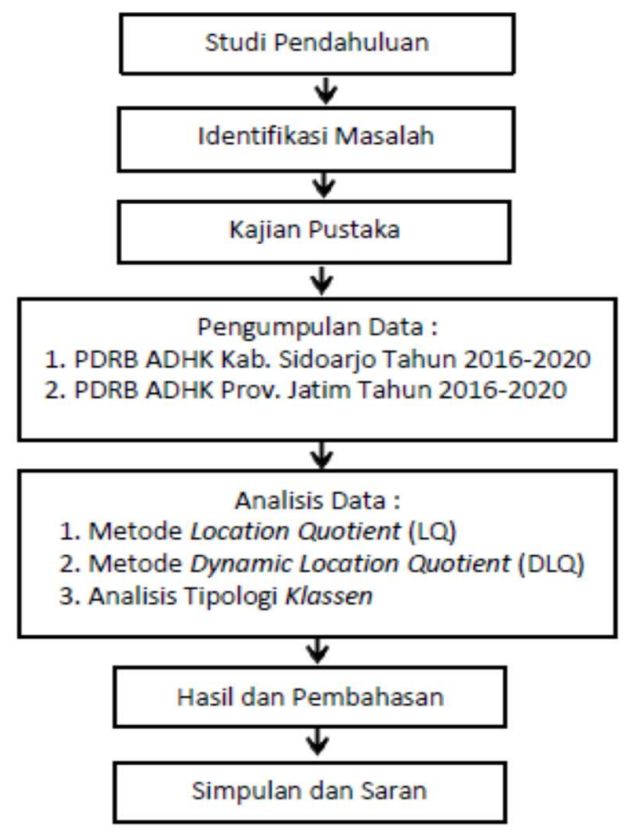

Gambar 1. Kerangka Pemikiran

Adapun variabel penelitian ini berupa 17 Sektor Lapangan Usaha sebagaimana tampak pada tabel 1. Output yang dihasilkan dihitung berdasarkan nilai rupiah Atas Dasar Harga Konstan tahun 2010.

Tabel 1. Variabel Penelitian 


\begin{tabular}{|c|l|}
\hline No. & \multicolumn{2}{|c|}{ VARIABEL PENELTIAN/SEKTOR LAPANGAN USAHA } \\
\hline 1 & Pertanian, Kehutanan, dan Perikanan \\
\hline 2 & Pertambangan dan Penggalian \\
\hline 3 & Industri Pengolahan \\
\hline 4 & Pengadaan Listrik dan Gas \\
\hline 5 & Pengadaan Air, Pengelolaan Sampah, Limbah dan Daur Ulang \\
\hline 6 & Konstruksi \\
\hline 7 & Perdagangan Besar dan Eceran; Reparasi Mobil dan Sepeda Motor \\
\hline 8 & Transportasi dan Pergudangan \\
\hline 9 & Penyediaan Akomodasi dan Makan Minum \\
\hdashline 10 & Informasi dan Komunikasi \\
\hline 11 & Jasa Keuangan dan Asuransi \\
\hdashline 12 & Real Estate \\
\hline 13 & Jasa Perusahanan \\
\hline 14 & Administrasi Pemerintahan, Pertahanan dan Jaminan Sosial Wajib \\
\hline 15 & Jasa Pendidikan \\
\hdashline 16 & Jasa Kesehatan dan Kegiatan Sosial \\
\hline 17 & Jasa lainnya \\
\hline
\end{tabular}

Sumber: Diambil dari data BPS, PDRB Kab. Sidoarjo Menurut Lapangan Usaha, 2016-2020

\section{HASIL PEMBAHASAN}

PDRB Provinsi Jawa Timur Atas Dasar Harga Konstan 2010 untuk tahun 2016-2020 dapat dilihat pada tabel 2. PDRB Jawa Timur digunakan sebagai pembanding terhadap PDRB Kabupaten Sidoarjo. Secara riil, pada PDRB Jawa Timur terjadi peningkatan output dari tahun 2016, kecuali tahun 2020. Terdapat 3 (tiga) sektor yang mempunyai kontribusi besar kepada Produk Domestik Regional Bruto Provinsi Jawa Timur yakni sektor Perdagangan Besar dan Eceran, Reparasi Mobil dan Sepeda Motor; sektor Pertanian, Kehutanan, dan Perikanan; dan sektor Industri Pengolahan. Dari 17 sektor yang ada, sektor yang terkecil kontribusinya yaitu sektor Pengadaan Air, Pengelolaan Sampah, Limbah dan Daur Ulang.

Tabel 2. PDRB Prov. Jatim 2016-2020

\begin{tabular}{|c|c|c|c|c|c|}
\hline \multirow{2}{*}{ Setha lapangan luath } & \multicolumn{5}{|c|}{ 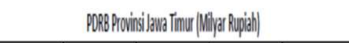 } \\
\hline & 2016 & 2017 & 2018 & 2019 & 2000 \\
\hline 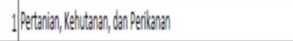 & 1607262,0 & 167,30600 & 16379990 & 165.78202 & $163: 38,7$ \\
\hline 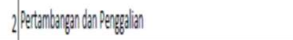 & 75,24040 & $80,656,0$ & 8253300 & 83787,60 & 0.2687 \\
\hline 3) noustipergalaben & $40,074,30$ & 04314,400 & 4659800 & 488852,20 & 4255944 \\
\hline 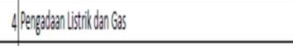 & 4483,00 & 459950 & 49990 & 45610 & 465.9 \\
\hline 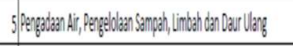 & 136670 & 15460 & 15550 & 15667 & 10605 \\
\hline 6) Konstocisi & 12734340 & $136,13,00$ & $165.14,20$ & 153609606 & 14862,4 \\
\hline 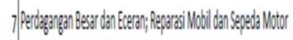 & $25,126,0$ & $282,23,30$ & 20.13630 & $307,40,90$ & 298004 \\
\hline 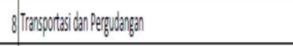 & $4.115,30$ & $4825 ; 30$ & 45712,40 & 48,474,4:4. & $43,00,3$ \\
\hline 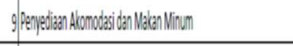 & 73399,90 & $79: 2020$ & 85.27350 & 9169940 & 8858606 \\
\hline 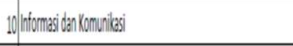 & 792170 & 86592,0 & 90,4620 & 91007060 & 1066126 \\
\hline 11. Bas Reargandean Averasi & $37,158,00$ & 3806450 & 3989990 & 4.13745: & 44493 \\
\hline 12 Real Estate & 24285,50 & $25,247,50$ & 268330 & $284,5,50$ & $2965,7.7$ \\
\hline 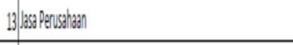 & 108040 & $1146,0,0$ & 1238500 & 1312800 & 122800,0 \\
\hline 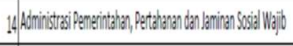 & 3166810 & 32369,0 & $33,70,20$ & 349443 & 34845,5 \\
\hline 15. Mas Pendidition & $37,68,70$ & 38831,50 & 44036,20 & 40,1900 & $45,600,0,0$ \\
\hline 16) las Kesertitan dan Kegitan Scsial & 9265,40 & 973,80 & 10.45570 & 1.27780 & 12595,5 \\
\hline 17) |asa ainya & 2028280 & 21203,30 & 2269960 & $23(532) 20$ & 203992. \\
\hline POPB & $1.455353,0$ & $1.822929,00$ & 1563141,100 & $1649,67,0,0$ & 16004990 \\
\hline
\end{tabular}

Sumber: Diolah dari data BPS, PDRB Prov. Jatim Menurut Lapangan Usaha, 2016-2020

Tabel 3 menunjukkan PDRB Kabupaten Sidoarjo Atas Dasar Harga Konstan 2010 untuk Tahun 2016-2020. Secara riil, terjadi peningkatan output dari tahun 2016 hingga tahun 2019, kecuali di tahun 2020. Sektor yang memberi kontribusi besar terhadap PDRB Kabupaten Sidoarjo adalah sektor Konstruksi; sektor Perdagangan Besar dan Eceran, Reparasi Mobil dan Sepeda Motor; dan sektor Industri Pengolahan. Dari 17 sektor yang ada, sektor yang terkecil kontribusinya yakni sektor Pengadaan Air, Pengelolaan Sampah, Limbah dan Daur Ulang.

Tabel 3. PDRB Kab. Sidoarjo 2016 - 2020 


\begin{tabular}{|c|c|c|c|c|c|}
\hline \multirow{2}{*}{ 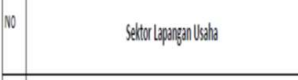 } & \multicolumn{5}{|c|}{ 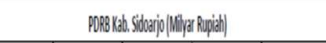 } \\
\hline & 2016 & 2017 & 2018 & 2019 & 2000 \\
\hline 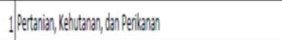 & 25042 & $256,51,1$ & 255,14 & 255827 & 202850 \\
\hline 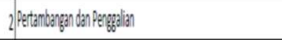 & 14559 & 151,15 & 15,19 & 15,500 & 101022 \\
\hline 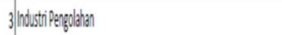 & 522748 & $6.159991]$ & 6599767 & 7284,260 & 72565,18 \\
\hline 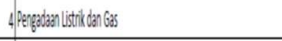 & 1133240 & 144,32 & 10040 & $100 ; 0$ & 100839 \\
\hline 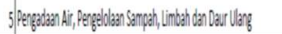 & $9,9,3$ & $9,0,4$ & 10,73 & 105,34 & 10,55 \\
\hline 6losostovis & 1.27796 & 1158253 & 12240,07 & 12525,58 & 12221,16 \\
\hline 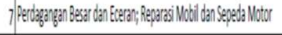 & 19:599393| & 2027,1212 & 2009,18 & 22702338 & 20734245 \\
\hline 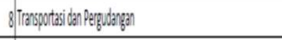 & $9833 \times 0$ & 1000,34 & $10.022,90$ & 9,2750 & 6645,26 \\
\hline 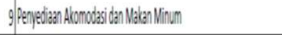 & 40232,28 & 4342 & 469,16 & 500880 & 46537,1: \\
\hline 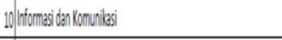 & $5: 32260$ & 504,45 & $586,3,1$. & 626552 & 6739929 \\
\hline 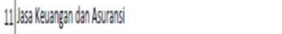 & 1.467272 & 409,05 & 1522,26 & 16640,3 & 1.0428 \\
\hline 12. Peal Statle & 1.5446 & L1986909 & 127181 & 134,15 & 1325,00 \\
\hline 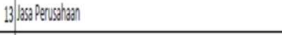 & 187,3 & $197,5$. & 20,900 & 24,606 & 20784 \\
\hline 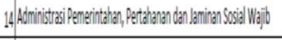 & $200,5,5=$ & 211837] & 2026,55 & 2280958 & 2424,6 \\
\hline 15 -3xpendidien & 145,28 & $155,1,3$ & 1565,10 & 163,5 & 1.658581 \\
\hline 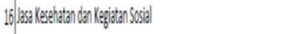 & 3872 & 40,2, & 43280 & 45899 & 49700 \\
\hline 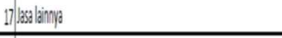 & 45960] & 48,6 & $49,2,2$ & 520,55 & 4964. \\
\hline PORB & 118179,19 & 1250390,0 & 132525294 & $100,42,39$ & 1352505,00 \\
\hline
\end{tabular}

Sumber : Diolah dari data BPS, PDRB Kab.Sidoarjo Menurut Lapangan Usaha, 2016-2020

\subsection{Analisis Location Quotient}

Hasil perhitungan dari analisis LQ dapat dilihat pada Tabel 4. Diketahui bahwa sektor Basis yang mempunyai kontribusi terhadap PDRB lebih besar dibanding sektor yang sama di wilayah tingkat atas atau $L Q>1$ adalah :

- sektor Industri Pengolahan

- sektor Pengadaan Listrik dan Gas

- sektor Transportasi dan Pergudangan

Sedangkan sektor Non Basis dengan kontribusi terhadap PDRB lebih kecil dibanding sektor yang sama di wilayah tingkat atas atau $\mathrm{LQ}<1$, yaitu :

- sektor Pertanian, Kehutanan, dan

Perikanan

- sektor Pertambangan dan Penggalian

- sektor Pengadaan Air, Pengelolaan

Sampah, Limbah dan Daur Ulang

- sektor Konstruksi

- sektor Perdagangan Besar dan Eceran, Reparasi Mobil dan Sepeda Motor

- sektor Penyediaan Akomodasi dan Makan Minum
- sektorInformasi dan Komunikasi

- sektor Jasa Keuangan dan Asuransi

- sektor Real Estate

- sektor Jasa Perusahaan

- sektor Administrasi Pemerintahan,

Pertahanan dan Jaminan Sosial Wajib

- sektor Jasa Pendidikan

- sektor Jasa Kesehatan dan Kegiatan Sosial

- sektor Jasa Lainnya.

Tabel 4. Analisis Location Quotient Kab. Sidoarjo Tahun 2016 - 2020

\begin{tabular}{|c|c|c|c|c|c|c|c|}
\hline \multirow{2}{*}{ 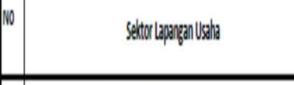 } & \multicolumn{5}{|c|}{ Loction Quntent } & \multirow{2}{*}{$\begin{array}{c}\text { Retr-Pate } \\
\text { lo }\end{array}$} & \multirow{2}{*}{ Keterazen } \\
\hline & 2016 & 2017 & 2018 & 2019 & 2020 & & \\
\hline 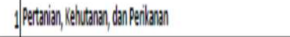 & 0,100 & 0,1800 & 0184 & 018: & 0,187 & 0,106 & Non besis \\
\hline 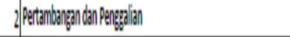 & $0,0,2$ & 0,022 & 0022 & 0,022 & 0,016 & 002 & Non bris \\
\hline 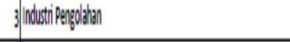 & 1,600 & 1608 & 1607 & 1691 & 1767 & 1608 & besis \\
\hline 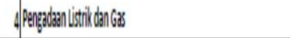 & 2,900 & 2960 & 2817 & 2775 & 2718 & 2W: & Bisis \\
\hline 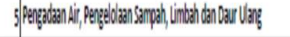 & 0,99 & 0,780 & 0,24 & 0,700 & 0,078 & 0,070 & Non bexis \\
\hline 6) Constrisisi & 1,00 & 1,005 & 0995 & 0,990 & 0999 & 0,995 & Non bisis \\
\hline 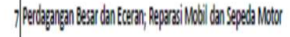 & 0,000 & 0080 & 0887 & 0.867 & 0,052 & 0,080 & Non besis \\
\hline 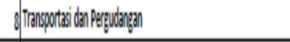 & 2,40 & 2013 & 2740 & 2355 & $17 \%$ & 2300 & Basis \\
\hline 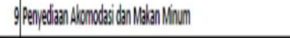 & 0,652 & 0,650 & ONA3 & 0,642 & 0663 & 0,650 & Non besis \\
\hline 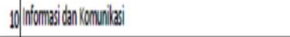 & $0,7 \%$ & 0,669 & 0,760 & 0,758 & 0,72 & 0,762 & Non bisis \\
\hline 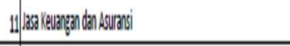 & 0,462 & 0,450 & 0,459 & 0,450 & Q 464 & $0,450$. & Non basis \\
\hline 12) (nas) State & 0,656 & 0563 & 0559 & 0,557 & 0,558 & 0,500 & Non basis \\
\hline 13. & 0,200 & 0204 & 0202 & 02000 & 0203 & $0202:$ & Non 1835 \\
\hline 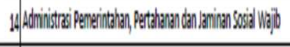 & 0,77 & 0,776 & 0,711 & 0780 & 0766 & 077\%. & Non basis \\
\hline 15. daspendolitan & 0,4 & OM: & 0,38 & 0,37 & 0,38 & 0,40 & Non bisis \\
\hline 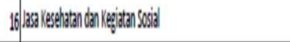 & $0,49=$ & 0,496 & 0.487 & 0,478 & 0,43 & 0,40 & Non bzis \\
\hline 17) $28 \mathrm{~s}$ im/ & 0,60: & 0,267 & 0265 & 0263 & 0262 & 0265 & Non basis \\
\hline
\end{tabular}

Sumber : Diolah dari data BPS, PDRB Kab.Sidoarjo

Menurut Lapangan Usaha, 2016-2020

\subsection{Analisis Dynamic Location Quotient}

Tabel 5 menunjukkan hasil perhitungan DLQ sesuai dengan formula yang sudah ditentukan. Dari tabel tersebut, sektor yang mempunyai potensi pengembangan lebih cepat dibandingkan sektor yang sama di wilayah tingkat atas atau DLQ $>1$, yaitu :

- sektor Pertanian, Kehutanan, dan

Perikanan 
- sektor Industri Pengolahan

- sektor Pengadaan Air, Pengelolaan

Sampah, Limbah dan Daur Ulang

- sektor Konstruksi;

- sektor Perdagangan Besar dan Eceran,

Reparasi Mobil dan Sepeda Motor;

- sektor Penyediaan Akomodasi dan Makan

Minum;

- sektor Informasi dan Komunikasi;

- sektor Jasa Keuangan dan Asuransi;

- sektor Real Estate;

- sektor Jasa Perusahaan;

- sektor Administrasi Pemerintahan,

Pertahanan dan Jaminan Sosial Wajib;

- sektor Jasa Pendidikan;

- sektor Jasa Kesehatan dan Kegiatan Sosial;

- sektor Jasa lainnya.

Sedangkan sektor yang mempunyai potensi pengembangan lebih lambat dibandingkan sektor yang sama di wilayah tingkat atas atau DLQ $<1$, yaitu :

- sektor Pertambangan dan Penggalian;

- sektor Pengadaan Listrik dan Gas;

- sektor Transportasi dan Pergudangan;

Tabel 5. Analisis Dynamic Location Quotient Kab. Sidoarjo Tahun 2016-2020

\begin{tabular}{|c|c|c|c|c|c|c|}
\hline \multirow{2}{*}{ 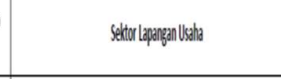 } & \multicolumn{3}{|c|}{ Kat. Sibario } & \multicolumn{2}{|c|}{ Aor. Stitin } & \multirow{2}{*}{ da } \\
\hline & $\mathrm{j}$ & tofil 11 & 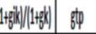 & litop [1: & 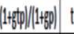 & \\
\hline 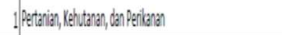 & 0,003 & 1,003 & $0,9830,0,04$ & 1.04 & 0.971 & 4. 1,05 \\
\hline 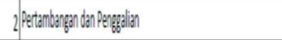 & $(0,057)$ & $0,2,8$ & 0,9560018 & 10,18 & 0965 & $4 \quad 0,78$ \\
\hline 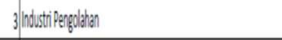 & 0,057 & 1,56 & $10360,0,45$ & 1,045 & 1001 & 4. 1,11 \\
\hline 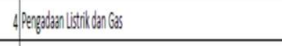 & $|0,024|$ & 0,976 & $0,057 \mid(00,02)$ & 0,988 & 0,955 & 4. 0,97 \\
\hline 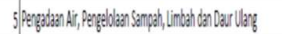 & 0,000 & 1,06 & 100800651 & 1,051 & 1006 & 1,05 \\
\hline gllosstobi & 0,033 & $1,1,33$ & $100130,0,00$ & 1.040 & 1006 & 1,03 \\
\hline 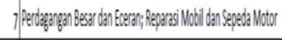 & 0,023 & $1,1,2$ & $10030,0,32$ & 1,032 & 0,998 & 1,02 \\
\hline 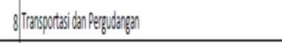 & $|0,0,2|$ & 0,966 & 09880,094 & 1,044 & 0,981 & 4. 0,0 \\
\hline 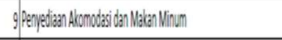 & 0,035 & 1,030 & 10090,036 & 1,036 & 1002 & 4. 1,07 \\
\hline 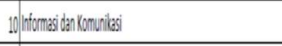 & $0,0,0$ & 1,000 & 100900077 & 1,077 & 1,02 & 4. 1,03 \\
\hline 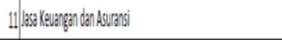 & 0,060 & 1,060 & $10060,0,28$ & 1,028 & 0,944 & 4. 1,05 \\
\hline 12 120: Estate & 0,040 & 1,49 & $10060,0,50$ & 1,050 & 1016 & 4 \\
\hline 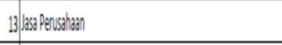 & 0,028 & 1,208 & $10080,0,030$ & 1,030 & 0,956 & 4 \\
\hline 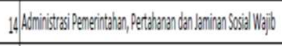 & 0,002 & 1,200 & $10000,0,24$ & 1,04 & 0990 & 1,04 \\
\hline 15: sesperditicen & 0,049 & 1,49 & $10060,0,52$ & 1,052 & 1,077 & 4 \\
\hline 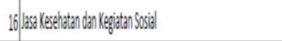 & $0,0,64$ & 1,06 & 100300073 & 1073 & 1088 & $4 \quad 1,02$ \\
\hline 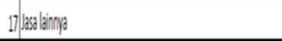 & $\mid 0,0001]$ & 0,090 & $0,9790,005$ & 1,055 & 0,972 & 4. 1,03 \\
\hline
\end{tabular}

Sumber : Diolah dari data BPS, PDRB Kab.Sidoarjo

Menurut Lapangan Usaha, 2016-2020

\subsection{Klasifikasi Tipologi Klassen}

Pemerintah daerah menyusun strategi perencanaan pembangunan dilakukan berdasarkan potensi sektoralnya melalui penentuan skala prioritas. Salah satu alat analisis yang digunakan untuk mengidentifikasi sektor prioritas atau sektor unggulan adalah dengan alat analisis Tipologi Klassen. Cara menganalisis Tipologi Klassen dengan membandingkan pertumbuhan ekonomi daerah dengan pertumbuhan ekonomi wilayah tingkat atas sebagai acuan dan membandingkan pertumbuhan PDRB dengan PDRB wilayah tingkat atas sebagai acuan.

Empat klasifikasi sektor dihasilkan dari analisis Tipologi Klassen dengan karakteristik yang berbeda sebagaimana tertera pada tabel 6, yaitu:

- Kuadran I, dimana LQ $\geq 1$ dan DLQ $>1$. Sektor pada Kuadran I dimana produk pada sektor bersangkutan tidak hanya dapat mencukupi kebutuhan di wilayah yang bersangkutan namun juga dapat diekspor ke luar wilayah dan adanya potensi pengembangan sektor yang bersangkutan tumbuh lebih cepat daripada sektor yang sama di wilayah tingkat atas (prospektif).

- Kuadran II, dimana LQ>1 dan DLQ $<1$. Sektor pada Kuadran II dimana produk pada sektor bersangkutan tidak hanya dapat mencukupi kebutuhan di wilayah yang bersangkutan namun dapat diekspor ke luar wilayah. Kontribusi sektor bersangkutan terhadap PDRB lebih besar daripada sektor yang sama di wilayah tingkat atas, namun potensi pengembangan sektor bersangkutan tumbuh lebih rendah daripada sektor yang sama di wilayah tingkat atas.

- Kuadran III, dimana LQ $<1$ dan DLQ $>1$. Sektor pada Kuadran III dimana kontribusi sektor bersangkutan terhadap PDRB lebih kecil daripada sektor yang sama di wilayah tingkat atas namun potensi pengembangan 
sektor bersangkutan tumbuh lebih cepat daripada sektor yang sama di wilayah tingkat atas.

- Kuadran IV, dimana LQ $<1$ dan $\mathrm{DLQ}<1$. Sektor pada Kuadran IV dimana kontribusi sektor bersangkutan terhadap PDRB lebih kecil daripada sektor yang sama di wilayah tingkat atas dan potensi pengembangan sektor bersangkutan tumbuh lebih rendah daripada sektor yang sama di wilayah tingkat atas.

Tabel 6. Klasifikasi Tipologi Klassen

\begin{tabular}{|c|c|c|}
\hline KRITERIA & $\begin{array}{c}\text { DLQ>1 } \\
\text { (Prospektif) }\end{array}$ & $\begin{array}{c}\text { DLQ<1 } \\
\text { (Tidak Prospektif) }\end{array}$ \\
\hline $\begin{array}{c}\text { LQ>1 } \\
\text { (Sektor Basis) }\end{array}$ & $\begin{array}{c}\text { Kuadran I } \\
\text { Sektor Basis, Prospektif }\end{array}$ & $\begin{array}{c}\text { Tipe II } \\
\text { Sektor Basis Tidak Prospektif }\end{array}$ \\
\hline $\begin{array}{c}\text { LQ<1 } \\
\text { (Sektor NonBasis) }\end{array}$ & $\begin{array}{c}\text { Tipe III } \\
\text { Sektor NonBasis, Prospektif }\end{array}$ & $\begin{array}{c}\text { Tipe IV } \\
\text { Sektor NonBasis Tidak Prospektif }\end{array}$ \\
\hline
\end{tabular}

Sumber : Diolah oleh penulis

Berdasarkan data pada tabel 4, tabel 5, dan tabel 6, maka sektor-sektor yang masuk pada Kuadran ke I, Kuadran ke II, Kuadran ke III, dan Kuadran ke IV terlihat pada tabel 7. Sektor yang memiliki kontribusi terhadap PDRB lebih besar daripada sektor yang sama di wilayah tingkat atas dan sekaligus memiliki potensi pengembangan yang tumbuh lebih cepat daripada sektor yang sama di wilayah tingkat atas (Kuadran I) adalah sektor Industri Pengolahan.

Tabel 7. Klasifikasi PDRB Kab. Sidoarjo berdasarkan Tipologi Klassen

\begin{tabular}{|c|c|}
\hline $\begin{array}{c}\text { KUADRAN-I } \\
\text { ( 1 Sektor Basis Prospektif) }\end{array}$ & KUADRAN-II \\
\hline
\end{tabular}

\begin{tabular}{|c|c|}
\hline - Sektor Industri Pengolahan & $\begin{array}{c}\text { (2 Sektor Basis Tidak } \\
\text { Prospektif) } \\
\text { - sektor Pengadaan Listrik } \\
\text { dan Gas } \\
\text { - sektor Transportasi dan } \\
\text { Pergudangan }\end{array}$ \\
\hline $\begin{array}{c}\text { KUADRAN-III } \\
\text { (13 Sektor Non Basis }\end{array}$ & $\begin{array}{c}\text { KUADRAN-IV } \\
\text { (1 Sektor Non Basis Tidak }\end{array}$ \\
- sektor Pertanian, & Prospektif) \\
Kehutanan, dan Perikanan & - sektor Pertambangan dan \\
- sektor Pengadaan Air, & \\
Pengelolaan Sampah, & \\
Limbah dan Daur Ulang & \\
- sektor Konstruksi & \\
- sektor Perdagangan Besar & \\
dan Eceran, Reparasi & \\
Mobil dan Sepeda Motor & \\
- sektor Penyediaan & \\
Akomodasi dan Makan & \\
Minum & \\
- sektor Informasi dan & \\
Komunikasi & \\
- sektor Jasa Keuangan dan & \\
Asuransi & \\
- sektor Real Estate & \\
- sektor Jasa Perusahaan & \\
- sektor Administrasi & \\
Pemerintahan, Pertahanan & \\
dan Jaminan Sosial Wajib & \\
- sektor Jasa Pendidikan \\
- sektor Jasa Kesehatan dan \\
Kegiatan Sosial \\
- sektor Jasa Lainnya. & \\
Sumber : Diolah oleh penulis & \\
\hline
\end{tabular}

\section{SIMPULAN}

Berdasarkan hasil pembahasan maka dapat diketahui bahwa yang menjadi basis pembangunan ekonomi di Kabupaten Sidoarjo tahun 2016 hingga tahun 2020 yakni sektor Industri Pengolahan, sektor Pengadaan Listrik dan Gas, dan sektor Transportasi dan Pergudangan.

Berdasarkan analisa Tipologi Klassen, terdapat 1 (satu) sektor, yaitu sektor Industri Pengolahan yang merupakan sektor basis prospektif (Kuadran I). Terdapat 2 (dua) sektor yaitu sektor Pengadaan Listrik dan Gas dan sektor Transportasi dan Pergudangan (kuadran II) yang merupakan sektor basis namun tidak prospektif dalam memberikan kontribusi pertumbuhan ekonomi daerah kedepannya. Sedangkan untuk 13 (tiga belas) sektor lainnya yaitu sektor Pertanian, Kehutanan, dan Perikanan; sektor Pengadaan Air, Pengelolaan Sampah, 
Limbah dan Daur Ulang; sektor Konstruksi; sektor Perdagangan Besar dan Eceran, Reparasi Mobil dan Sepeda Motor; sektor Penyediaan Akomodasi dan Makan Minum; sektor Informasi dan Komunikasi; sektor Jasa Keuangan dan Asuransi; sektor Real Estate; sektor Jasa Perusahaan; sektor Administrasi Pemerintahan, Pertahanan dan Jaminan Sosial Wajib; sektor Jasa Pendidikan; sektor Jasa Kesehatan dan Kegiatan Sosial; dan sektor Jasa Lainnya (Kuadran III) meskipun merupakan sektor non basis namun prospektif kedepannya. Sedangkan untuk 1 (satu) sektor lainnya yaitu sektor Pertambangan dan Penggalian (Kuadran IV) adalah sektor non-basis yang tidak prospektif.

Mempertimbangkan skala prioritas bagi daerah dalam mendorong pertumbuhan ekonomi daerahnya, maka terdapat 14 sektor yang memiliki prospektif dalam pembangunan daerah Kabupaten Sidoarjo (yang berada di Kuadran I dan III) sebagai berikut: sektor Industri Pengolahan; sektor Pertanian, Kehutanan, dan Perikanan; sektor Pengadaan Air, Pengelolaan Sampah, Limbah dan Daur Ulang; sektor Konstruksi; sektor Perdagangan Besar dan Eceran, Reparasi Mobil dan Sepeda Motor; sektor Penyediaan Akomodasi dan Makan Minum; sektor Informasi dan Komunikasi; sektor Jasa Keuangan dan Asuransi; sektor Real Estate; sektor Jasa Perusahaan; sektor Administrasi Pemerintahan, Pertahanan dan Jaminan Sosial Wajib; sektor Jasa Pendidikan; sektor Jasa Kesehatan dan Kegiatan Sosial; dan sektor Jasa Lainnya. Terdapat 1 (satu) sektor unggulan yang berkontribusi signifikan pada pertumbuhan ekonomi Kabupaten Sidoarjo, yaitu sektor Industri Pengolahan.

\section{SARAN/REKOMENDASI}

\footnotetext{
Berkenaan dengan simpulan tersebut diatas hal analisis sektor unggulan Kabupaten Sidoarjo Tahun 2016-2020 terdapat 1 (satu) sektor unggulan yang
}

berkontribusi signifikan pada pertumbuhan ekonomi Kabupaten Sidoarjo yaitu sektor Industri Pengolahan. Untuk itu strategi perencanaan pembangunan di Kabupaten Sidoarjo dapat dilakukan dengan memberikan prioritas tinggi kepada pembangunan dan pengembangan sektor Industri Pengolahan untuk mengakselerasi pertumbuhan ekonomi. Disamping itu didorong kedepannya untuk 13 sektor nonbasis yang memiliki prospektif untuk diakomodir dengan mempertimbangkan skala prioritas (scale of priority) dalam perencanaan pembangunan daerah Kabupaten Sidoarjo sebagai representasi kebijakan pembangunan daerah yang berorientasi kepada kepentingan publik dalam pembangunan daerah. 


\section{DAFTAR PUSTAKA}

Anggara, Sahya dan Sumantri, Ii. (2016). Administrasi Pembangunan: Teori dan Praktik. CV. Pustaka Setia Bandung.

Arsyad, Lincolin. (1999). Pengantar Perencanaan dan Pembangunan Ekonomi Daerah. BPFE UGM Yogyakarta.

Arsyad, Lincolin. (2004). Pembangunan Ekonomi Daerah. BPFE UGM Yogyakarta.

Badan Pusat Statistik. (2021). Produk Domestik Regional Bruto Kabupaten Sidoarjo menurut Lapangan Usaha 2016-2020. Badan Pusat Statistik Kabupaten Sidoarjo.

Badan Pusat Statistik. (2021). Produk Domestik Regional Bruto Provinsi Jawa Timur menurut Lapangan Usaha 2016-2020. Badan Pusat Statistik Jawa Timur.

Berita Resmi Statistik Kabupaten Sidoarjo. (2021). Pertumbuhan Ekonomi Kabupaten Sidoarjo Tahun 2020. Badan Pusat Statistik Kabupaten Sidoarjo.

Budi T, Kristian. Sektor Basis Di Kabupaten Blitar, Jawa Timur: Analisis PDRB Kabupaten Blitar Tahun 2010-2016. Inovasi. Vol 16 No 2.

Caiden, Gerald E. 1982. Public Administration. 2nd Ed. Palisades Publishers California.

Daryanto, Arief dan Hafizrianda. (2010). Metode Kuantitatif untuk Perencanaan Pembangunan Ekonomi Daerah: Konsep dan Aplikasi. IPB Press Bogor.

Hakim, Abdul. (2019). Sektor Unggulan dan Pergeseran Sektoral Kabupaten Gresik 2011-2017 Dalam Perspektif Pembangunan Ekonomi Regional. OECONOMICUS Journal of Economics. Vol 3 No 2.

Irmansyah, Maulana. (2019). Analisis Sektor Unggulan Yang Ada Di Kabupaten Mojokerto Jawa Timur. Jurnal Dinamika Ekonomi Pembangunan. Vol 2 No 1.

Kartasasmita, Ginandjar. (1997). Administrasi Pembangunan. LP3S Jakarta.

Peraturan Pemerintah Nomor 8 Tahun 2008 tentang Tahapan Tata Cara Penyusunan Pengendalian dan Evaluasi Pelaksanaan Rencana Pembangunan Daerah.

Rohmah, Siti Nia dan Cahyono, Hendry. (2021). Analisis Sektor Ekonomi Potensial dan Pengembangan Wilayah Guna Meningkatkan Pertumbuhan Ekonomi di Kabupaten Bangkalan Tahun 2015-2019. Independent: Journal Of Economics. Vol 1 No 2.

Tambunan, Tulus H. (2001). Perekonomian Indonesia. Penerbit Ghalia Jakarta. 